\title{
Determination of allyl isothiocyanate, capsaicin and dihydrocapsaicin in pungent liquid samples
}

\author{
Sang-Soo Kim and Jong-Moon Choi ${ }^{1, \star}$ \\ Guns Team, Guns \& Explosives Safety Technology Association, Seoul 121-875, Korea \\ ${ }^{1}$ Department of Korean Medicine \& Processing, Hanzhong University, Donghae, Gangwon 240-713, Korea \\ (Received October 5, 2012; Revised November 30, 2012; Accepted December 5, 2012)
}

\section{자극성 액체시료 중 Alyl Isothiocyanate, Capsaicin and Dihydrocapsaicin 정량에 관한 연구}

\author{
김상수 · 최종문 ${ }^{1, \star}$ \\ 총포화약안전기술협회 총포팀, ${ }^{1}$ 한중대학교 간호보건대학 약재가공학과 \\ (2012. 10. 5. 접수, 2012. 11. 30. 수정, 2012. 12. 5. 승인)
}

\begin{abstract}
The allyl isothiocyanate, capsaicin and dihydrocapsaicin as main components in self defense sprays were determined by gas chromatography-mass spectrometer (GC-MS). Although self defense spray was used to protect by myself, a social problem could be caused by the hazard of spray chemical due to use pungent liquid. To identify this, the $\mathrm{pH}$ of pungent liquid solutions, solubility to detergents, the existence of other materials and the types and amounts of pungent material in spray chemicals were investigated in this work. Finally, the amounts of allyl isothiocyanate, capsaicin and dihydrocapsaicin as pungent materials in them were determined by GC-MS. The $\mathrm{pH}$ of chemicals were about 5.7 as weak acid, the detergents can emulsify them with water well. And they did not contain fluorescent materials and hazard organic solvents. The pungent components in three real samples were only allyl isothiocyanate $[47,600 \mathrm{mg} / \mathrm{kg}(47.6 \%)]$ in one sample, and mixtures with capsaicin [228 mg/kg 368 mg/kg (1.14\% 1.84\%)] and dihydrocapsaicin [224 mg/kg 414 mg/kg (1.12\% 2.07\%)] in the others, respectively.
\end{abstract}

요 약: 자극성 액체의 주성분인 allyl isothiocyanate, capsaicin 및 dihydrocapsaicin을 기체크로마토그래피 -질량분석기로 정량하는 방법에 대하여 연구하였다. 방호용인 목적이지만 스프레이 약제의 유해성과 품 질관리는 또 다른 사회적 문제를 야기할 가능성이 있다. 이를 위해 시판 유통되고 있는 호신용 스프레이 로부터 자극성 액체의 $\mathrm{pH}$, 약제의 세척을 위한 세제의 용해정도, 기타 물질의 사용유무를 검토하였다. 마지막으로 자극성 성분으로 이용되는 allyl isothiocyanate, capsaicin 및 dihydrocapsaicin의 함량을 GC-MS 로 정량하였다. 약제의 $\mathrm{pH}$ 는 5.7 정도로 약산성이었고, 세제를 사용할 경우 약제의 유화되는 정도가 우 수하였고, 실험에 사용된 액체에는 형광물질 및 유해 유기용매가 포함되지 않았다. 이전 연구 결과를 바 탕으로 기체크로마토그래피-질량분석기를 이용하여 분석한 실제시료 3 가지에 포함된 성분은 한 가지 제

$\star$ Corresponding author

Phone : +82-(0)33-520-9295 Fax : +82-(0)33-522-4150

E-mail : jmchoi@hanzhong.ac.kr 
품에서는 allyl isothiocyanate 단일 성분[47,600 mg/kg (47.6\%)]이었고, 나머지 두 제품은 capsaicin[228 mg/ $\mathrm{kg} 368 \mathrm{mg} / \mathrm{kg}(1.14 \% \sim 1.84 \%)]$ 과 dihydrocapsaicin [224 mg/kg 414 mg/kg (1.12\% 2.07\%)] 혼합성분으로 구성되어 있었다.

Key words: pungent liquid, allyl isothiocyanate, capsaicin, dihydrocapsaicin, GC-MS

\section{1. 서 론}

호신을 목적으로 하는 스프레이에 대한 매스컴 광 고를 최근 많이 볼 수 있다. 흔히 가스총으로 혼동하 는 이런 물품들은 압축가스의 내장 여부에 따라 구별 되며, 내장된 압축가스를 이용한 경우 총포 - 도검 - 화 약류 등 단속법에 따라 관할 경찰서장의 허가를 받아 야 하는 기준이 생긴다. ${ }^{1}$ 그러나 제품 상단의 펌프 부 분을 눌러 발생한 압력에 의해 작동되는 호신용 스프 레이는 휴대가 간편하고, 법적 제한이 없다는 장점 때 문에 널리 유통, 이용되고 있으나 추진력이 약하고 연 속적인 발사가 어렵다는 단점이 있다.

국내에서 사용되는 호신용품의 내장 약제로는 주 로 마늘, 후추 및 고추에서 추출한 capsaicinoid이다. ${ }^{2-4}$ 흔히 capsaicinoid를 oleoresin capsicum 또는 capsaicin 이라 하며 고추의 매운 맛을 나타내는 성분으로 주 성분이 capsaicin과 dihydrocapsaicin이고, 극미량의 nordihydrocapsaicin, homodihydrocapsaicin 및 homocapsaicin 형태로 존재한다. ${ }^{5}$ 또 겨자 등에서 추출한 mustard oil로 알려진 allyl isothiocyanate ${ }^{6,7}$ 를 많이 이용하는데 겨자의 톡 쏘는 특유의 맛과 향 및 강한 항균성이 있어 식품 및 향신료로 널리 이용되고 있 지만 ${ }^{8}$ 이들은 눈을 자극하는 최루작용이나 코의 자극 및 일시적인 호흡곤란을 야기하기도 한다. 이에 비 해 수입 호신용품 약제는 주로 CS (o-chlorobenzylidene malononitrile $)^{9 \sim 11}$ 과 oleoresin capsicum이 이용되는데 $\mathrm{CS}$ 는 암 유발 잠재성 및 지속성 때문에 사용이 감 소추세에 있다. 또한 천연물질이기는 하나 고농도의 약제는 인체에 치명적일 수 있으므로 일반적으로 희 석해서 이용해야 하며 이때 일부 수입제품은 독성 유기물로 희석하는 경우가 있어 유해성 문제가 대두 되고 있다.

전술한 바와 같이, 호신용스프레이가 최근 소비자들 로부터 몇 가지 이유로 인해 각광을 받고 있으나 법 적제재를 받지 않고 온 - 오프라인을 통해 누구나 손쉽 게 유통, 소비가 이루어져 범죄에 악용할 우려나 오작 동으로 인한 폐해, 특히 제조업체의 난립화와 덤핑판 매 등으로 약제 성분 및 함량 등의 품질이 제대로 관
리되지 못하고 있다. 따라서 이에 대한 품질관리차원 에서 정확한 분석기법이 마련되어야 한다.

지금까지 allyl isothiocyanate과 oleoresin capsicum 의 정량분석 및 유해성을 검토한 예는 다음과 같다.

Barbero 등 ${ }^{10}$ 은 capsaicinoid들을 여러 가지 유기용 매를 이용하여 가압용매추출법으로 추출하여 분석하 였다. Peush 등른 capsaicinoid들을 초임계유체크로마 토그래프를 이용하여 분리 - 추출하였다고 보고하였다. Saria 등 ${ }^{13}$ 은 고성능액체크로마토그래피법으로 분리 · 추출하였다. Krajewska 등 ${ }^{14}$ 은 기체크로마토그래프를 이용하여 추출 - 분리하였다. Araceli 등 ${ }^{15}$ 은 후추로부터 allyl isothiocyanate를 고체상추출과 기체크로마토그래 프-질량분석기(GC-MS)를 이용하여 분석하였다. Seo 등 11 은 수입산 겨자원두로부터 열 추출법으로 allyl isothiocyanate 성분을 추출하여 기체크로마토그래피법 으로 정량하였다. William등 16 은 겨자에 대한 인체의 관능실험을 실시하였다.

지금까지 살펴본 바와 같이, mustard oil이나 oleoresin capicum의 주성분인 allyl isothiocyanate 또는 capsaicin 은 식품의 향신료로 널리 이용되어왔던 물질로서 이 들에 포함된 자극성 성분을 인체 방어용으로의 응용 은 최근에 와서 활발히 진행되었다. 따라서 지금까지 이에 대한 정량은 대개 크로마토그래프를 이용한 식 품, 향신료에 대한 연구가 대부분이었고, 호신용품 약 제 분석에 관련된 목적은 아니었다.

따라서 본 연구는 시중에서 판매되고 있는 호신용 스프레이 3종류를 선택하여 내장된 자극성 약제의 성 분 및 함량 분석을 GC-MS를 이용하여 수행하였다. 또한 내장된 자극성 액체 약제의 $\mathrm{pH}$, 세척제에 대한 용해성, 유해성 유기용매의 사용유무 등을 함께 검토 하였다.

\section{2. 실 험}

\section{1. 시약 및 기기}

2.1.1. 시약

실험과정에서 사용한 물은 1차 증류수를 Barnstead NANO pure ultrapure water system으로 거른 2차 탈 
Table 1. Instrumental conditions of gas chromatograph-mass spectrometer

\begin{tabular}{ll}
\hline \hline Gas Chromatograph & \\
\hline Inlet temperature & $350{ }^{\circ} \mathrm{C}$ \\
Injection volume & $1 \mu \mathrm{L}$ \\
Split ratio & $1 / 20$ \\
Carrier gas/flow rate & $\mathrm{He} / 1.5 \mathrm{~mL} / \mathrm{min}$ \\
Column & Elite-1 \\
Oven temperature & Initial temp. : $150{ }^{\circ} \mathrm{C}$ for $1 \mathrm{~min}$ \\
program & Ramp time : $10{ }^{\circ} \mathrm{C} / \mathrm{min}$ to $250{ }^{\circ} \mathrm{C}$ \\
Run time & Hold time : $9 \mathrm{~min}$ \\
\hline Mass spectrometer & $20 \mathrm{~min}$ \\
\hline MSD mode & $\mathrm{SIM} / \mathrm{Scan}$ \\
Scan mode & 60 amu $300 \mathrm{amu}$ \\
\hline
\end{tabular}

염수를 사용하였다.

표준시약 allyl isothiocyanate과 oleoresin capsicum (capsaicin과 dihydrocapsaicin의 함량비는 65\%:35\%)은 독일 Fluka사의 시약급을 사용하였다. Dichloromethane, methanol, ethanol, acetone, hexane, chloroform, benzene, toluene, glycerin 등의 유기용매는 일본 Junsei사의 특 급시약을 정제하지 않고 그대로 사용하였다.

호신용 스프레이 약제의 용해성 검사를 위한 세척 제로서 시판용 세면비누와 주방용 세제를 사용하였고, 분석시료로 사용된 자극성 액체는 온라인 판매점에서 구매한 호신용 스프레이 3 종류에서 채취한 것을 사용 하였다.

\subsection{2. 기기}

가스크로마토그래프-질량분석기는 미국 Perkinelmer사(모델 Clarus600, USA)이며, 기기측정조건은 Table 1과 같다. 시료의 $\mathrm{pH}$ 측정은 Metrohm사의 유리 전극이 장착된 미국 Metrohm사, 모델 $826 \mathrm{pH}$ 미터를 사용하였다. 시료는 화학저울(영국 Precisa사, 모델 205A SCS)를 사용하여 채취하였으며, 추출을 위해 초 음파세척기(미국 Branson사, 모델 3210)를 사용하였다. 시료 중 형광염료는 자외선램프(미국 Spectroline사, 모델 ENF-240C)를 사용하여 확인하였다.

\section{2. 실험방법}

\subsection{1. $\mathrm{pH}$ 측정}

측정용 $\mathrm{pH}$ 미터의 유리전극을 탈염수로 세척하고, $\mathrm{pH} 4$ 와 7 완충용액으로 $\mathrm{pH}$ 를 보정한 후 일정량을 취 한 시료용액에 유리전극을 직접 담구어 $\mathrm{pH}$ 를 측정하

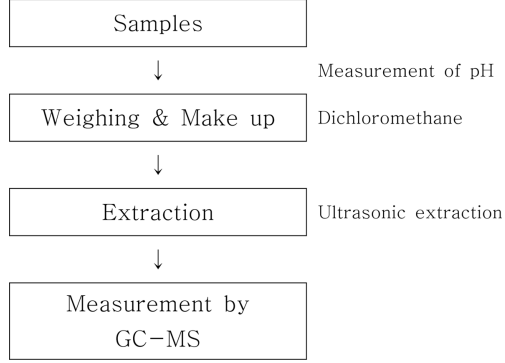

Fig. 1. Experimental procedure.

Table 2. Conditions for GC/MS analysis of organic solvents

\begin{tabular}{ll}
\hline \hline GC Conditions & \\
\hline Inlet Temperature & $350{ }^{\circ} \mathrm{C}$ \\
Injection Volume & $1 \mu \mathrm{L}$ \\
Split ratio & $1 / 100$ \\
Carrier gas/flow rate & $\mathrm{He} / 1.5 \mathrm{~mL} / \mathrm{min}$ \\
Column & Elite- 1 \\
Oven Temperature & $\cdot$ Initial Temp. : $40{ }^{\circ} \mathrm{C}$ for $5 \mathrm{~min}$ \\
Program & $\cdot$ Ramp. : $10{ }^{\circ} \mathrm{C} / \mathrm{min}$ to $200{ }^{\circ} \mathrm{C}$ \\
Run Time & $20 \mathrm{~min}$ \\
\hline Mass Spectrometer Conditions \\
\hline MSD mode & $\mathrm{SIM} / \mathrm{Scan}$ \\
Scan range & $(30 \sim 200) \mathrm{amu}$ \\
Selective ion mass & $(31,32,43,46,57,58,61,74,78$, \\
\hline
\end{tabular}

였다.

\subsection{2. 용해성 평가}

비누 및 중성세제 $2.0 \mathrm{~g}$ 정도를 각각 정확히 달아 $500.0 \mathrm{~mL}$ 부피플라스크에 넣고, 교반기로 완전 용해 시킨 후 방치하여 발생한 거품이 완전히 없어지게 하 였다. 이후 다시 표선까지 탈염수를 채운 다음 자석교 반기에서 교반하여 용액이 완전히 혼합되게 한 후 조 용히 방치하여 $0.4 \%(w / V)$ 용액을 조제하였다. 제조된 중성세제용액 $10 \mathrm{~mL}$ 를 정확히 취하여 $20 \mathrm{~mL}$ 마개가 달린 바이알 병에 넣은 후 약제시료 5 방울씩 가하고, 세차게 5 회 혼합한 후 방치하여 용액의 상태를 육안 으로 관찰하였다.

\subsection{3. 시료용액의 조제}

Allyl isothiocyanate 표준용액 은 allyl isothiocyanate 일정량을 달아 희석용매인 dichloromethane에 용해시 켜 $50 \%$ 표준원액을 제조하여 마개가 있는 용기에 보 관하면서 필요할 때마다 희석하여 사용하였다. 
Capsaicin과 dihydrocapsaicin 측정용 표준용액은 직접 원하는 농도에 해당하는 무게를 달아 dichloromethane 에 용해시켜 제조하였다.

분석용 실제시료는 시판되는 호신용 스프레이 용 기에 담긴 약제를 회수하여 밀폐용기에 넣고, 일정량 의 약제를 취해 각각 10 배씩 희석시킨 후 마개가 있는 용기에 넣어 초음파세척기로 약 15 분간 처리하였다. 처리된 시료용액으로부터 allyl isothiocyanate, capsaicin 및 dihydrocapsaicin을 분석하기 위해서 Table 1, 그리 고 실제시료에 포함된 희석용매의 종류를 검토하기 위해서는 Table 2에 제시된 기기조건으로 수행하였다.

\section{3. 결과 및 고찰}

\section{1. 자극성 액체의 $\mathrm{pH}$}

가장 이상적인 피부는 대략 4.5 6.5 정도의 약산성을 띠는데 ${ }^{17}$ 호신용 약제는 얼굴을 포함한 인체의 피부에 닿아야 효과를 발휘할 수 있기 때문에 약제가 강한 산 성이나 염기성을 띤다면 피부나 안구의 손상을 야기할 가능성이 있다. 이런 유해성 문제 때문에 약제의 $\mathrm{pH}$ 를 측정해 보았고, 그 결과를 Fig. 2에 수록하였다.

Fig. 2에서 볼 수 있듯이, 생리식염수의 $\mathrm{pH}$ 는 7.82 로 거의 중성을 나타낸 것에 비해 시료의 $\mathrm{pH}$ 는 모두 5 6정도의 약산성을 나타내었다. 이로서 시판되는 호 신용품의 자극성 약제성분으로 인한 2차적인 피부조 직의 손상은 크게 야기하지 않을 것으로 판단하였다.

\section{2. 자극성 액체의 물리적 성질}

\subsection{1. 용해성}

이미 전술한 바와 같이 호신용 약제는 방호를 목적

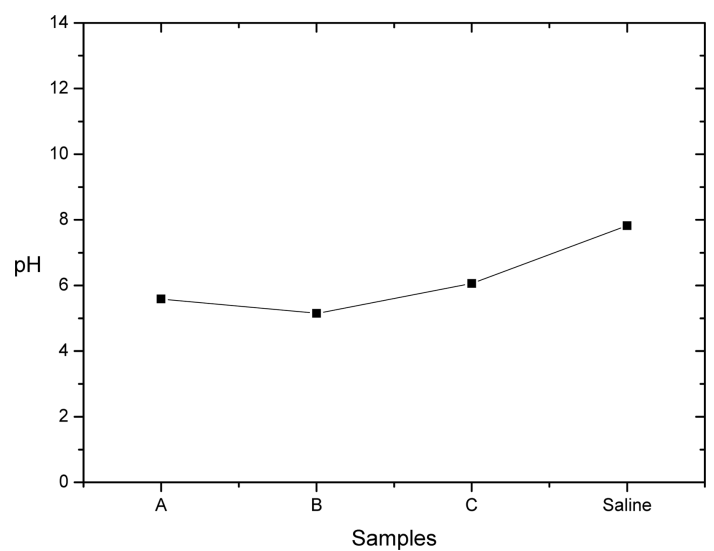

Fig. 2. The $\mathrm{pH}$ of real samples (temp. $22.4{ }^{\circ} \mathrm{C} \pm 0.3{ }^{\circ} \mathrm{C}$ ).
으로 하고는 있으나 피부 또는 의류에 잔류하는 약제 를 제거할 필요가 있다. 이를 위해 일반적인 수돗물, 식염수, 비눗물, 주방세제 등을 이용하여 약제의 용해 정도를 검토하였다.

이를 위해 수돗물, 식염수, $0.4 \%$ 비눗물과 주방용 중성 합성세제로 실험하였다(4 종류 용액의 온도는 $17{ }^{\circ} \mathrm{C}, \mathrm{pH}$ 는 각각 $7.2,7.7,7.4$ 및 7.8). 우선 각 용액 을 일정량 취하여 실제시료 3 가지를 첨가한 후 강하 게 5 회 흔들어주고 방치시켜 용기 내에서 일어나는 현상을 육안으로 관찰하여 평가하였다.

수돗물과 식염수에 시료를 첨가한 경우, 시료들은 친수성이 전혀 없어 이중층이 형성되었고, 5 회 강하게 흔들어준 후에도 이중층이 파괴되지 않는 것으로 보 아 모든 시료들은 소수성을 띠는 것으로 판단하였다.

이에 비해 $0.4 \%$ 비눗물과 중성세제를 사용할 경우 처음에는 이중층을 하였으나 5 회 정도 세차게 흔들어 준 후에는 에멀젼 형성과 함께 상분리가 없어지는 현 상이 관찰되었다. 이는 비누와 세제에 포함된 계면활 성제의 영향으로 생각된다. 따라서 분사기 약제성분은 소수성이며 이를 용해시키기 위해서는 계면활성제가 필요함을 알 수 있었다.

\subsection{3. 희석용매의 사용과 종류}

호신용 스프레이 약제는 자극성이 강하므로 고 농 도로 사용할 경우 피부자극과 쇼크 정도가 심하기 때 문에 가급적 저 농도로 사용해야 한다. 그러나 용해성 실험에서 알 수 있듯이 모든 분사기 약제가 소수성이 므로 희석용매가 필요하며 이로 인해 약제의 균일성 에 문제가 발생할 수 있다. 또 저 농도로 사용하기 때 문에 가능한 희석용매는 휘발성 용매를 사용하는 것 이 유리할 것이다.

국내에서는 주로 ethanol을 분사기 약제의 희석용으 로 사용하지만 외국 제품의 경우 isopropyl alcohol이 나 trichloroethylene과 같은 유해 유기용매를 사용하는 사례가 있다. 따라서 총포 - 도검 - 화약류 등 단속법 시 행령 9조(제조기술의 기준) 3항 1 호에 의거하여 독성 유기용매의 사용여부를 검토해보아야 할 것이다.

이를 위해 산, 알칼리, 기름 및 알코올 등에 강한 성질을 가지고 있으나 유기용매에는 잘 녹는 합성수 지에 시료 약제를 떨어뜨려 정성적으로 유기용매의 사용여부를 판단해 보았다.

Sample A의 경우 합성수지가 격렬히 용해되는 현 상을 관찰할 수 있었는데 이는 sample A에는 합성 수 지를 용해시킬 만한 유기용매가 존재할 수 있다는 의 


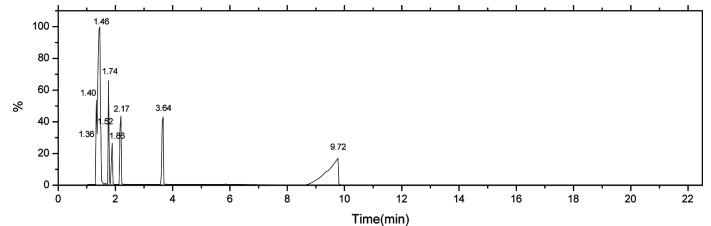

Fig. 3. GC chromatograms of several organic solvents. methanol $(1.31 \mathrm{~min})$, ethanol $(1.40 \mathrm{~min})$, acetone $(1.16 \mathrm{~min})$, dechloromethane $(1.52 \mathrm{~min})$, hexane $(1.74 \mathrm{~min})$, chloroform (1.86 $\mathrm{min}$ ), benzene (2.17 $\mathrm{min})$, toluene (3.64 $\mathrm{min})$, glycerin $(9.72 \mathrm{~min})$.

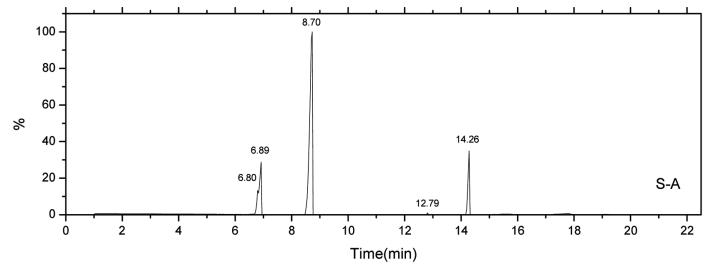

(a) Sample A

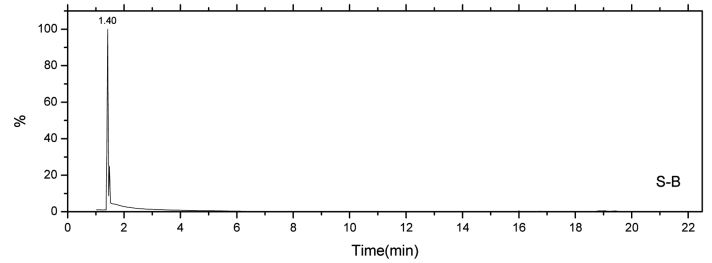

(b) Sample B

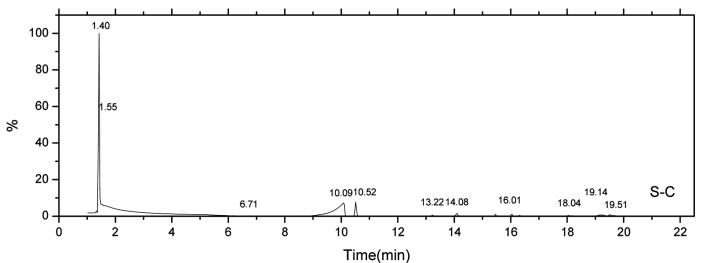

(c) Sample C

Fig. 4. GC chromatograms of sample A, B and C.

미로 판단된다. 이에 비해 나머지 2개의 시료에서는 아무런 현상을 관찰할 수 없었다.

따라서 유기용매의 종류를 정량적으로 밝히기 위해 보편적으로 사용하는 9 가지 유기용매인 methanol, ethanol, acetone, dichloromethane, hexane, chloroform, benzene, toluene 및 glycerin을 혼합한 시험용액을 조 제하여 Table 1의 측정조건에서 split ratio(1/100), temperature program에서 initial temp. $\left(40{ }^{\circ} \mathrm{C}\right.$ for $\left.5 \mathrm{~min}\right)$, ramp time $\left(10{ }^{\circ} \mathrm{C} / \mathrm{min}\right.$ to $\left.200{ }^{\circ} \mathrm{C}\right)$, scan range $(30 \mathrm{amu}$ 200 amu) 및 selective ion mass를 해당 유기용매의 분자량으로 변경시켜 기체크로마토그래프로 측정하였 다(Fig. 3). 이때 변경된 기기조건을 Table 2에 수록하
였다.

Fig. 3에 나타난 바와 같이, 각 유기용매의 피크가 확실히 구별될 수 있음을 알 수 있었다.

이렇듯 유기용매의 확인이 가능한 것으로 판단되어 실제시료인 분사기 약제를 기체크로마토그래프에 1 $\mu \mathrm{L}$ 씩 주입하여 각 분사기 약제 내에 포함된 유기용매 가 무엇인지 확인하였다(Fig. 4).

Fig. 4에서 나타난 바와 같이, sample A는 ethanol 의 머무름시간에서 아무런 피크가 나타나지 않았고, 머무름시간 6.89 분과 8.70 분에서 휘발성이 강한 성 분이 검출되었다. 따라서 이를 분리하여 질량스펙트 럼으로 조사한 결과 이는 allyl isothiocyanate 성분임 을 확인하였다. 결국 allyl isothiocyanate 성분만으로 도 충분한 휘발성을 얻을 수 있음을 알 수 있었고, allyl isothiocyanate 때문에 합성수지가 sample $\mathrm{A}$ 를 가했을 때 격렬히 용해되는 현상을 확인할 수 있었다.

그러나 sample $\mathrm{B}$ 와 $\mathrm{C}$ 에서는 머무름시간 1.40 분에 서 나타난 ethanol 피크이외에 특징적 피크가 나타나 지 않았으나 sample C에서 머무름시간 10.52 분에서 출현한 피크는 본 연구에서 고려한 유기용매가 아닌 다른 용매성분으로 판단된다.

\subsection{4. 기타 성분의 유무}

한편 분사기 약제에는 증거 채취 목적으로 외국제 품에는 미량의 형광물질을 첨가하는 경우도 있다. 따 라서 실제시료에도 형광물질을 첨가했는지에 대해 검 토하였다. 일정 크기의 섬유에 해당 시료들을 분사하 여 완전히 건조시킨 후 자외선램프로 쪼여본 결과 사 용한 시료들에서는 형광물질이 검출되지 않았다.

\section{4. 실제 시료 분석}

지금까지 얻어진 결과를 바탕으로, 시료에 사용된 자극성 약제에 포함된 allyl isothiocyanate와 capsaicin 및 dehydrocapsaicin을 정량하였다.

이를 위해 실험방법에 의해 미리 제조된 고농도 allyl isothiocyanate 용액과 capsaicin와 dihydrocapsaicin이 혼합된 표준시약 각각을 일정량 취하여 dichloromethane 으로 적당히 희석하여 일련의 검정곡선용 표준용액들 을 조제하였다. 조제된 표준용액을 기체크로마토그래 프로 측정하여 얻어진 피크의 면적으로 정량용 검정 곡선을 작성하였다. 이때 얻어진 검정곡선의 상관계수 는 allyl isothiocyanate, capsaicin 및 dihydrocapsaicin이 각 각 0.99451, 0.99997 및 0.99807로 직선성이 우수하였 다(Fig. 5). 

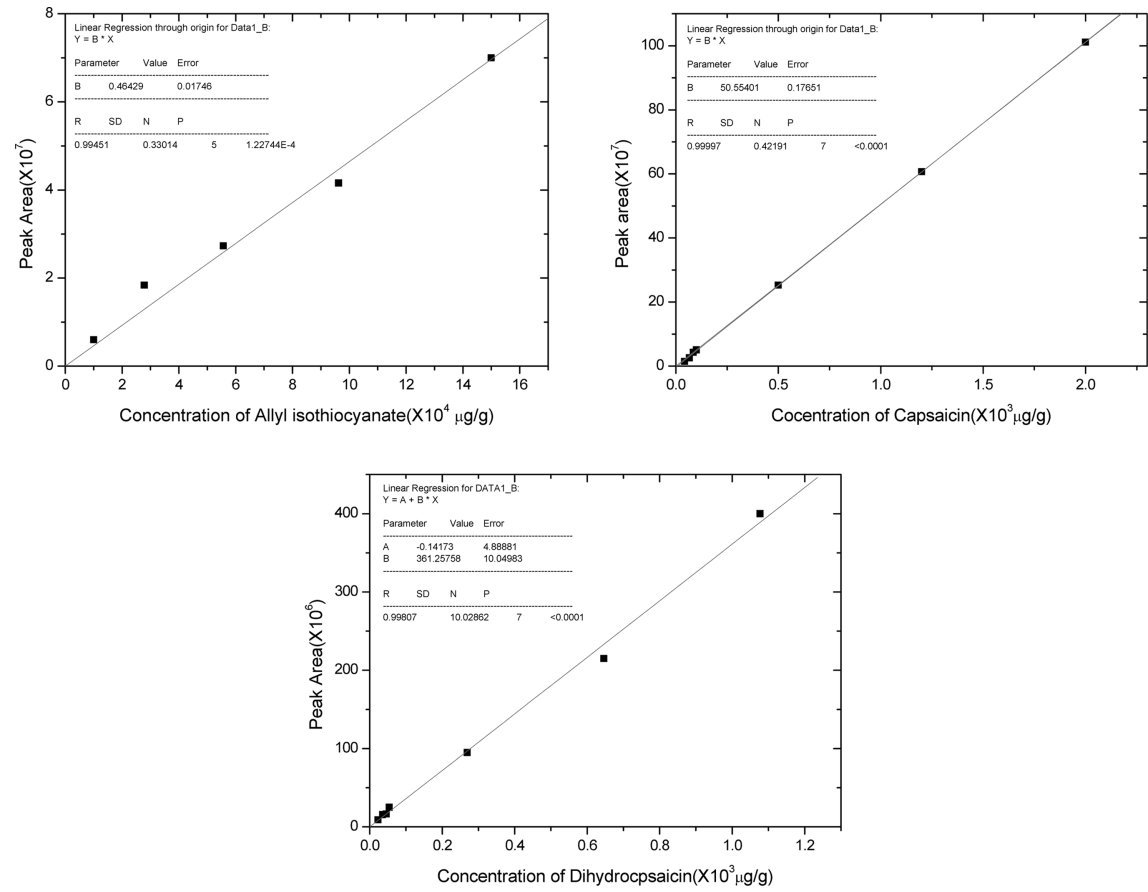

Fig. 5. The calibration curves of ally isothiocyanate, capsaicin and dihydrocapsaicin.

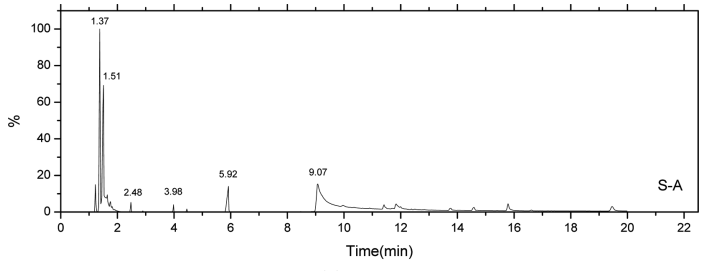

(a) Sample A
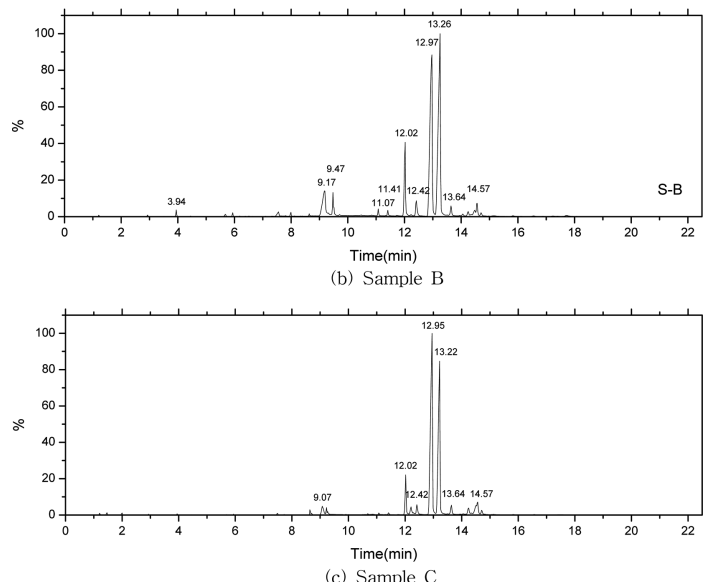

Fig. 6. GC chromatograms of real samples(A, B and C).

한편 3 가지 종류의 실제시료 일정량을 취하여 dichloromethane으로 적당한 농도로 희석하여 크로마
Table 3. The analytical results of real samples

\begin{tabular}{ccccc}
\hline \hline \multirow{2}{*}{ Sample } & \multicolumn{4}{c}{ Contents[mg/kg (\%)] } \\
\cline { 2 - 5 } & $\begin{array}{c}\text { Allyl } \\
\text { isothiocyanate }\end{array}$ & Capsaicin & $\begin{array}{c}\text { Dihydro- } \\
\text { capsaicin }\end{array}$ & Solvent \\
\hline S-A & $47,600(47.6)$ & - & - & - \\
S-B & - & $368(1.84)$ & $414(2.07)$ & ethanol \\
S-C & - & $228(1.14)$ & $224(1.12)$ & ethanol \\
\hline
\end{tabular}

토그램을 얻었다(Fig. 6).

Fig. 6과 같이, sample A에서는 머무름시간 1.37 분 에서 피크가 출현하였고, 이를 질량스펙트럼을 통해 확인한 결과 allyl isothiocyanate로 확인되었으며, 이때 검출된 농도를 환산한 결과 $47,600 \mathrm{mg} / \mathrm{kg}(47.6 \%)$ 로 비교적 고농도를 사용했음을 알 수 있었다. 전술한 바 와 같이 sample A에서는 다른 유기용매가 관찰되지 않았으므로 allyl isothiocyanate만으로도 충분한 충진 압력을 나타낼 수 있다고 판단하였다.

이에 비해 sample B와 C에서는 allyl isothiocyanate 는 전혀 검출되지 않았고, 모두 머무름시간 12.98 분 과 머무름시간 13.26 분에서만이 피크가 검출되었다. 이를 질량스펙트럼으로 확인한 결과 머무름시간 12.98 분 피크의 성분은 capsaicin이었고, 머무름시간 13.26분 피크의 성분은 dihydrocapsaicin으로 확인되었 
다. 그러나 특이하게 sample B에서는 capsaicin의 함 량보다 dihydrocapsaicin의 함량이 더 높았다. 이는 아 마도 sample B의 약제는 다른 원료로부터 추출한 capsaicin을 사용한 것으로 보인다. 이때 포함된 함량은 환산한 결과 sample B에서는 capsaicin이 $368 \mathrm{mg} / \mathrm{kg}$ (1.84\%), dihydrocapsaicin은 $414 \mathrm{mg} / \mathrm{kg}(2.07 \%)$, sample $\mathrm{C}$ 에서는 capsaicin이 $228 \mathrm{mg} / \mathrm{kg}$ (1.14\%), dihydrocapsaicin 은 $224 \mathrm{mg} / \mathrm{kg}(1.12 \%)$ 로 계산되었다.

최근 capsaicin이 인공적으로 합성 가능하게 되어 capsaicin만 $100 \%$ 함유가 가능하게 되었지만 천연물질 로부터 추출한 capsaicin은 capsaicin이 dihydrocapsaicin 보다 더 많은 양 포함되었다는 보고에 의해 본 연구 에 사용한 호신용 약제는 모두 천연물질로부터 추출 한 성분을 사용하였음을 알 수 있었다. 지금까지의 결 과를 Table 3에 수록하였다.

\section{4. 결 론}

지금까지 온라인 판매점에서 시판되는 호신용 분사 기 약제를 기체크로마토그래프 및 기체크로마토그래 프-질량분석기를 이용하여 분석한 결과 다음과 같은 몇 가지 결론을 얻을 수 있었다.

1. 시판되는 호신용 분사기 약제의 $\mathrm{pH}$ 는 $~ 5.7$ 정도 의 약산성을 나타내어 인체에 2 차적 손상을 야기하지 않을 것으로 판단된다.

2. 분사기 약제의 용해성은 중성 계면활성제가 포함 된 세제를 사용하면 완전히 용해시킬 수 있음을 알 수 있었다.

3. 약제로서 allyl isothiocyanate를 사용할 경우 자극 성 성분의 균질도와 희석을 위한 유기용매는 필요하 지 않으나 capsaicin 또는 dihydrocapsaicin을 약제로 할 때 국내 시판용 제품에는 에탄올을 사용하였고, 다 른 성분은 검출되지 않았다.

4. Allyl isothiocyanate 성분을 약제로 사용할 경우 합 성수지를 용해시키는 것으로 보아 인체에 유해성으로 고려하여 사용 농도의 규제가 필요할 것으로 보인다.

5. 실제시료 3 종류에 본 방법을 응용해 본 결과 1 개 시료에서는 allyl isothiocyanate이 검출되었고, 나머 지 2가지에서는 모두 capsaicin 과 dihydrocapsaicin이 각각 $228 \mathrm{mg} / \mathrm{kg}(1.14 \%) \quad 368 \mathrm{mg} / \mathrm{kg}(1.84 \%)$ 과 224 $\mathrm{mg} / \mathrm{kg}(1.12 \%) \sim 414 \mathrm{mg} / \mathrm{kg}(2.07 \%)$ 범위로 검출되었으 며, 제시된 방법이 자극성 약제성분 분석에 유용하게 사용될 수 있음을 확인하였다.

\section{참고문헌}

1. 총포 · 도검 · 화약류 등 단속법 제 12 조.

2. J. M. Lundberg and A. Saria, Nature, 302, 251-253 (1983).

3. R. Gamse, Arch. Pharmacol., 320, 205-216 (1982).

4. R. M. Virus and G. F. Gebhard, Life Sci., 25, 12731284 (1979).

5. G. Barbero, M. Palma and C. Barroso, J. Agric. Food Chem., 54, 3231-3236 (2006).

6. M. G. Ettlinger, G. R. Dateo, B. W. Harrison, T. J. Mabry, C. P. Thompson, Proc. Natl. Acad. Sci. U.S.A. 47, 1875-1880 (1961).

7. A. Kjar, Acta. Chem. Scad., 22, 3324-3326 (1968).

8. K. I. Seo, K. S. Kang and K. H. Shim, Korean J. Food Sci. Technol., 29(1), 51-56 (1997).

9. J. C. Mitchell and W. P. Jordan, Raphanus sativus. Br. J. Dermatol., 91, 183-189 (1974).

10. B. Ballantyne and D. W. Swanston, Arch. Toxicol., 40, 75-95 (1978)

11. L. H. Horsley, "Advances in Chemistry Series", No 6, 73, Washingtone 1952.

12. M. Peush, E. Muller-Seitz, M. Petz, A. Muller and E. Anklam, Z Lebensm Unters Forsch A, 204, 351-355 (1977).

13. A. Saria, F. Lemberck and G. Skofitsch, J. Chromatogr, 208, 41-46 (1981).

14. A. Krajewska and J. Powers, J. Chromatogr., 409, 223233 (1987).

15. P-A. Araceli, R-M. Erika and A-S. Luis, J. Chromatogr. A., 1216, 2843-2847 (2009).

16. S. C. William, L. D. Michael, J. K-V. Melissa and C. A. Bruce, Regulatory Toxicology and Pharmacology, 58, 173-180 (2010)

17. Mi-Young Ham, J. Beau. Tricho., 4(1), 25-38 (2008). 